\title{
AUSTRALIA'S MOST DIVERSE CRAYFISH HABITAT?
}

\section{J. Morey AND G. Hollis}

Department of Conservation and Natural Resources, 71 Hotham St, Traralgon, Vic. 3844, Australia

\begin{abstract}
Morey, J. and Hollis, G., 1997. Australia's most diverse crayfish habitat? Memoirs of the Museum of Victoria 56(2): 667-669.

Labertouche Creek, a tributary of the Tarago River in West Gippsland, arguably has the most diverse freshwater crayfish assemblage in Australia. Six crayfish species are known from the creek, including the rare and vulnerable Warragul Burrowing Crayfish, Engaeus sternalis, the only known location of this species in Australia (Horwitz, 1990, 1992). Other species of burrowing crayfish found are E. hemicirratulus, E. cunicularius, and E. quadrimanus. Two species of Euastacus (Spiny Freshwater Crayfish) are also known from these waters, Euastacus yarraensis and E. kershawi (Gippsland Spiny Crayfish). A third species, E. woiwuru, is possibly present, as the creek is shown to be within this species' range.
\end{abstract}

\section{Introduction}

Labertouche Creek, a tributary of the Tarago River in West Gippsland, possibly has Australia's most diverse freshwater crayfish assemblage, with six species of freshwater crayfish (four species of burrowing crayfish of the genus Engaeus (Decapoda: Parastacidae) and two spiny crayfish of the genus Euastacus (Decapoda: Parastacidae) known to be present and a seventh species (E. woiwuru) suspected of being present, as the creek is within its range (Morgan, 1986). Adult burrowing crayfish are generally small, total length rarely exceeding $100 \mathrm{~mm}$, whereas the adult spiny crayfish are considerably larger than $100 \mathrm{~mm}$ in total length.

A survey was conducted to confirm the presence of the Warragul Burrowing Crayfish, Engaeus sternalis (Clark), and determine the suitability of pitfall trapping as a survey technique for the species. E. sternalis has been classified as Endangered by the Department of Conservation and Natural Resources on the basis of its single confirmed location and as a taxa in danger of extinction in Victoria and whose survival is unlikely if the factors causing their decline continue operating' (CNR, 1993, IUCN, 1983). The species was listed under the Flora and Fauna Guarantee Act 1988 in March 1993 (SAC, 1993).

Specimens were collected in pit fall traps adjacent to the creek following heavy spring rain during this survey. Three pitfall lines, consisting of between 6 and 41 traps, constructed from 90 $\mathrm{mm}$ PVC tubing cut into $200 \mathrm{~mm}$ lengths, (with tin lids in the bottom), were established in grazing land adjacent to Labertouche Creek, $50 \mathrm{~m}$ downstream from the 1982 collection site of $E$. sternalis (Horwitz, pers comm). The pitfall traps were distributed at approximately $0.5 \mathrm{~m}$ intervals at a number of different locations at the study site to determine whether $E$ sternalis utilises different areas along the creek. This included pitfall traps located along the bank of the creek $(<1 \mathrm{~m}$ to edge), perpendicular to the creek (approx $10 \mathrm{~m}$ ) and in the banks of the creek. Several traps installed in the banks of the creek were lost during floods. Trapping commenced on 26 Jun 1995 and continues to the present. A $200 \mathrm{~mm}$ high driftfence was erected between pitfall traps to act as a superficial barrier directing greater numbers into the pits than would otherwise occur. This driftfence however, was removed on $31 \mathrm{Jul} 1995$ due to the presence of cattle at the study site. Pitfall traps were checked mostly at 2-5 day intervals.

Results of pittfall trapping to mid-November are summarised in Table 1. No crayfish were caught in traps between 26 June and 8 August. All species were collected from September onwards, usually after rainfall, however $E$. sternalis was only captured after rainfall. $E$. sternalis and $E$. cunicularius have so far only been collected within $0.5 \mathrm{~m}$ to the creek bank, whereas $E$. quadrimanus and $E$. hemicirratulus were recorded along the bank and up to $8 \mathrm{~m}$ perpendicular to the bank within the cleared grazing area. The number of adults collected was almost the same as the number of juveniles (14 adults, 15 juveniles), indicating both age classes responded equally to, or took advantage of, the wet weather to disperse on the surface. It is still not known how E. sternalis reaches the surface, as none of its tunnel systems so far investigated has come to the surface (Horwitz, 1990a). 
Table 1. Engaeus species collected in pitfall traps adjacent to Labertouche Creek 26 Jul to 20

Nov 1995. $\mathrm{F}=$ Female, $\mathrm{M}=$ Male, $\mathrm{u}=$ Sex unknown, $\mathrm{ad}=$ adult, juv = juvenile, $\mathrm{E}$ quad/cunic $=$ unable to identify.

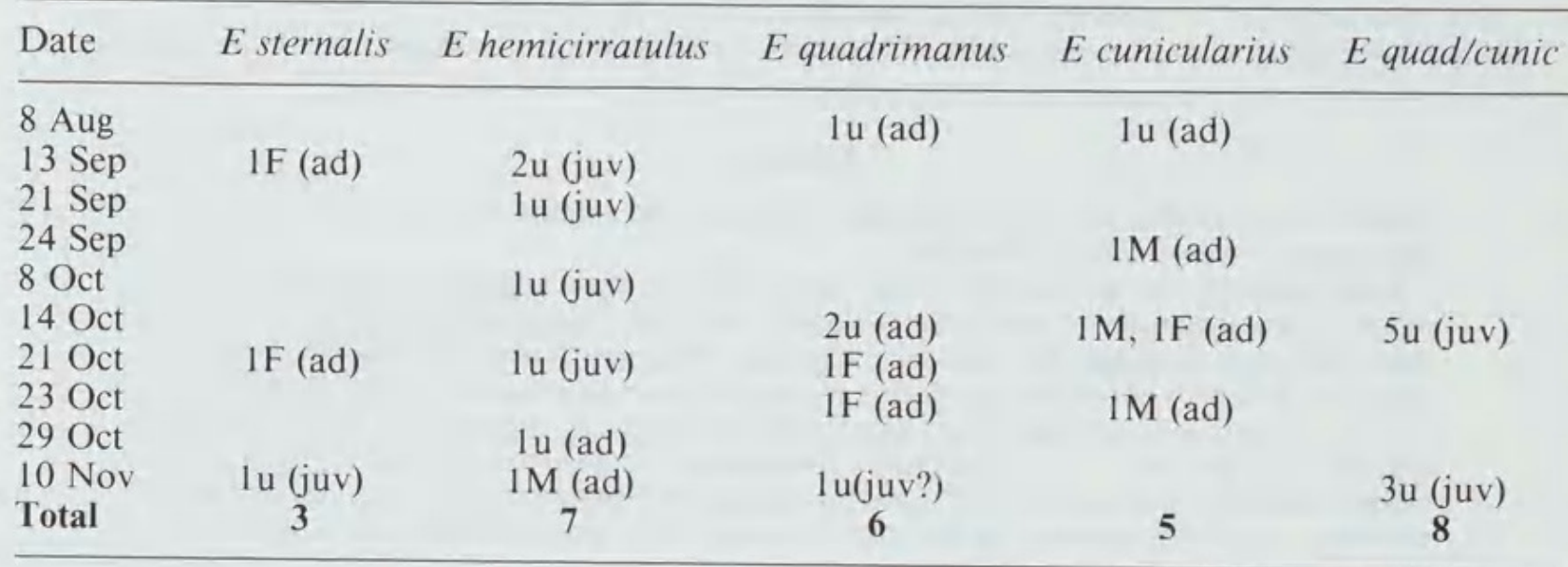

\section{Species encountered}

Engaeus sternalis. Despite extensive searching, the only known location in Australia of this species is on Labertouche Creek and prior to this survey, was found in complex burrow systems in clayey soils in the creek bank (Horwitz, 1990a. 1990b). Nothing is known about its biology or ecology This species is easily identified by its pale yellow-grey colour, a covering of fine downy hairs on its carapace and dimorphic chelae, and very small eyes.

Engaeus hemicirratulus Smith and Schuster, is a common burrowing species easily identified by its bright orange claws, many stiff hairs and very short antennae. Their burrows typically have a fan shaped chimney, with tunnels descending obliquely to chambers which are occasionally just below the ground surface. Males and females are frequently found together in the same burrow and are usually accompanied by juveniles (Horwitz, 1990b). Burrows are typically in yellow-orange clay dominated soils, which was originally covered in dense wet forest. This species is common and widespread throughout its range in Gippsland, usually above an altitude of $100 \mathrm{~m}$.

Engaeus cunicularius (Erichson) is a common species, generally brown and with the top side of dactyl (the smaller movable part of the claw), slightly rough or granulated (Horwitz, 1990b). Often found in sympatry with $E$ quadrimanus, and in similar habitat types (Horwitz, 1990b). It constructs burrows connected to the water table and/or to permanent water (Horwitz and
Richardson, 1986; Horwitz, 1990b). E. cunicularius is found from near the Otways in western Victoria throughout south eastern Victoria, the Bass Strait islands and Tasmania (Horwitz, 1990b).

Engaeus quadrimanus Clark, another common species, is very similar to $E$. cunicularius but the dactyl is smooth. These two can only be distinguished from each other as adults; if total length (tip of claws to tip of tail) is $50-60 \mathrm{~mm}$. It is considered a lowland species and found in a range of vegetation types from ferny gullies to near rainforest, and in swamps and creeks (Horwitz, 1990b). E. quadrimanus constructs burrows, usually with more than one opening and often with conical, pelleted chimneys, down to the water table (Horwitz, 1990b, Horwitz and Richardson, 1986). Distribution is from north of Melbourne to Mallacoota, near the VictoriaNew South Wales border (Horwitz, 1990b).

Euastacus yarraensis (McCoy) is generally dark olive green with white and orange claws. The spines on the abdomen and some bumps on the carapace are orange with white tips/centres. Females mature at close to $40 \mathrm{~mm}$ Occipital Carapace Length, (the distance from the rear of the eye socket to the centre of the posterior of the carapace). Berried females have been collected in surveys in September through to November (Morgan, 1986). E. yarraensis is found from the Tarago River through to the Otways in south western Victoria. 
Euastacus kershawi (Smith) (Gippsland Spiny Crayfish) is usually dark olive green, often with orange markings on the under-side, but with no white on the claws, and has sharp spines on the front legs and abdomen. It can grow large, although specimens over $120 \mathrm{~mm}$ carapace length are uncommon. Females are generally sexually mature at OCL greater than $85 \mathrm{~mm}$, although some specimens appear to be sexually mature between $50 \mathrm{~mm}$ to $80 \mathrm{~mm}$ OCL (Morgan, 1986). Recent surveys by the first author indicate this species is very slow growing, averaging an annual increase of only $7 \mathrm{~mm} \mathrm{OCL}$. Specimens have occasionally been found many metres away from permanent water. Some individuals construct burrows of type $1 b$ or 2 (Horwitz and Richardson, 1986), adjacent to river banksFound from the Tarago River to almost the New South Wales border in southerly flowing rivers and streams.

A third species of this genus, Euastacus woiwuru Morgan is possibly present, as the creek is within the species' range, (Morgan, 1986) but as yet has not been recovered during surveys. It is similar in size to $E$ yarraensis, but relatively poorly spined (Morgan, 1986).

Prior to this survey, E sternalis was only found by destructive sampling of the creek bank, however results show that pitfall trapping is a feasible alternative of survey for this cryptic species, as well as for some other species of burrowing crayfish. It appears that $E$. sternalis, along with other sympatric species, respond to rainfall and increasing ground temperature for above ground dispersal.

Preliminary results confirm Horwitz's opinion that $E$. sternalis is confined to the creek bank, although no doubt the species could be found in adjacent damp areas with more extensive surveys. A community awareness program and site protection works are currently being undertaken to protect the habitat of Engaeus sternalis.

\section{Acknowledgments}

Permission from the landholder, $\mathrm{Mr}$ Barry Whiting, to survey on his property is greatly appreciated. The project was funded by a grant from the Australian Heritage Commission.

\section{References}

CNR, 1993. Threatened Fauna in Victoria. Department of Conservation and Natural Resources: Melbourne.

Horwitz, P., 1990a. The conservation status of Australian freshwater Crustacea. Australian National Parks and Wildlife Service Report Series No 14.

Horwitz, P., 1990b. A taxonomic revision of species in the freshwater crayfish genus Engaeus Erichson (Decapoda: Parastacidae). Invertebrate Taxonomy 4: 427-614.

Horwitz, P. H.J. and Richardson, A. M., 1986. An ecological classification of the burrows of Australian freshwater crayfish. Australian Journal of Marine and. Freshwater Research 37: 237-242.

IUCN, 1983. The IUCN Invertebrate Red Data Book. International Union for Conservation of Nature and Natural Resources, Switzerland.

Morgan, G.J., 1986. Freshwater crayfish of the genus Euastacus Clark (Parastacidae) from Victoria. Memoirs of the Museum of Victoria 47: 1-57.

SAC (Scientific Advisory Committee, Flora and Fauna Guarantee), 1993. Final recommendation on a nomination for listing: Engaeus sternalis. Department of Conservation and Natural Resources, Victoria. 


\section{$2 \mathrm{BHL}$ Biodiversity Heritage Library}

Morey, J and Hollis, G . 1997. "Australia's most diverse crayfish habitat?" Memoirs of the Museum of Victoria 56(2), 667-669.

https://doi.org/10.24199/j.mmv.1997.56.68.

View This Item Online: https://www.biodiversitylibrary.org/item/122980

DOI: https://doi.org/10.24199/j.mmv.1997.56.68

Permalink: https://www.biodiversitylibrary.org/partpdf/258155

\section{Holding Institution}

Museums Victoria

\section{Sponsored by}

Atlas of Living Australia

\section{Copyright \& Reuse}

Copyright Status: Permissions to digitize granted by rights holder.

This document was created from content at the Biodiversity Heritage Library, the world's largest open access digital library for biodiversity literature and archives. Visit BHL at https://www.biodiversitylibrary.org. 